堆 積 学 研 究, 48号, 61-66, 1998

J. Sed. Soc. Japan. No. 48，61-66， 1998

\title{
Occurrence of iron silicate oolites in Mahanadi deltaic sediments of Orissa, India
}

\author{
N. K. Mahalik*, Wataru Maejima**, B. K. Mohapatra*** and B. R. Nayak***
}

\begin{abstract}
Extensive occurrence of iron silicate oolites have been observed in the Upper Pleistocene subsurface sediments of Mahanadi delta along Orissa coast. They are usually associated with dark grey to black, shell-bearing marine deposits now occuring inland at depths ranging from 100 to $300 \mathrm{~m}$ beneath the present ground level. They show concentric layering with or without a nucleus and are believed to have been formed by the precipitation in amorphous state of hydrous iron silicates of variable composition approximating between glauconite and chamosite. They were deposited in a shallow marine reducing environment.
\end{abstract}

Key words : chamosite, deltaic sediments, glauconite, iron silicate oolites, shallow marine reducing environment

\section{INTRODUCTION}

During the early part of the nineties, the Danish International Development Agency (DANIDA) undertook extensive groundwater investigation along the coastal saline tract of Mahanadi delta along Orissa coast. Drilling along a $40 \mathrm{~km}$ stretch of land across the southwestern sector of the delta (Fig. 1) provided valuable information on the nature of sediments, marine life, subsurface stratigraphy, depositional environment, ground water occurrence, sea-level fluctuation etc. (Mahalik, 1995). It was observed that a regionally extensive horizon of dark grey to black, shell-bearing thick sediment exists around $100 \mathrm{~m}$ depth beneath the ground, which has been termed as Tolapada Formation by Mahalik (1995). Carbon dating of the shell fragments in this horizon gives a Late Pleistocene age. The dark grey sediments invariably contain

Received : May 12, 1998, Accepted : July 10, 1998

* Department of Geology, Utkal University, Bhubaneswar 751004, India

** Department of Geosciences, Osaka City University, Osaka 558-8585, Japan

*** Regional Research Laboratory, Bhubaneswar 751013, India substantial quantities of organic shells (gastropods, bivalves, corals), foraminifers and greenish to dark grey oolites. This paper describes the characteristics of oolites in respect of their morphology, chemistry, mineralogy and discusses their environment of deposition.

\section{MATERIALS AND METHODS}

The oolite deposits were observed in bore holes drilled at Purushottamballav, Jaganathballav, Bhagbanpur, Sakhigopal, Chandanpur, Kadua, Sadanandapur, Birgobindpur, Puri etc. by DANIDA. They all lie along the southwestern sector of Mahanadi delta in Puri district of Orissa State (Fig. 1). Marine sediments, deposited within the subsurface, 30 to $35 \mathrm{~km}$ landward off the present coast indicate late Pleistocene marine transgression. Oolite samples were retrieved from Puri and Bhagbanpur bore holes, in loose state by hydraulic rotary drilling. Oolites of Puri were obtained from $140 \mathrm{~m}$ depth and those of Bhagbanpur were retrieved from $300 \mathrm{~m}$ depth; the locations are shown in Fig. 1.

The morphology of oolite samples were studied under Leitz optical microscope. Phillips XRD was used to find out its degree of crystallinity and 


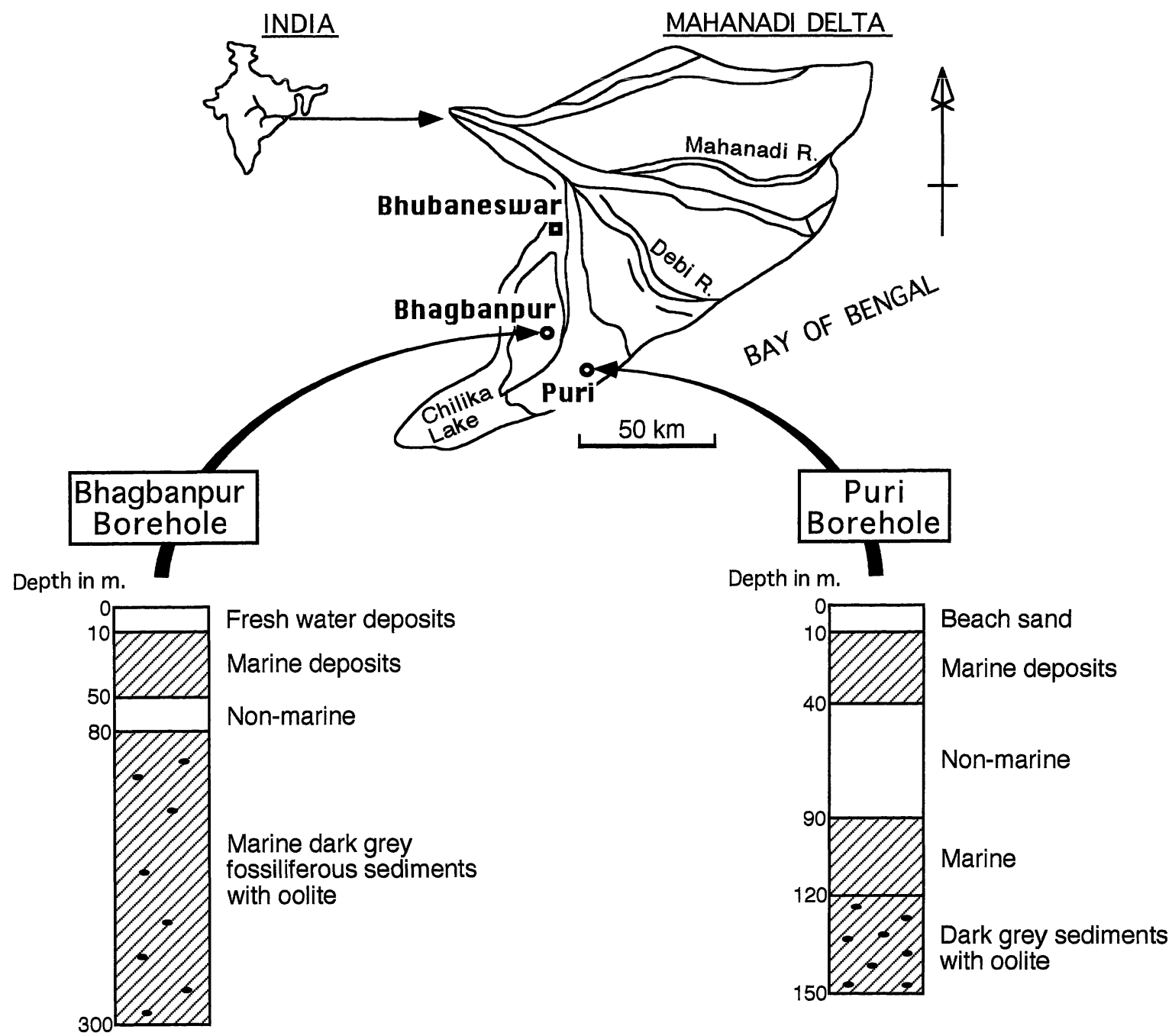

Fig. 1 Boreholes showing oolite-bearing sediments in Mahanadi delta.

mineralogy. Chemical analysis of the bulk sample was taken up by routine titration technique. The mineral chemistry of a few grains (14 nos.) was obtained by SX-50 CAMECA (France) electron probe.

\section{MORPHOLOGY AND ASSOCIATION}

The oolites are fine mustard seed like grains with spherical to ellipsoidal shapes and vary in size from $0.5 \mathrm{~mm}$ in diameter to finer sizes. They show varying colours: dirty green, steel grey, greenish yellow and dull brown. Oolites are associated with dark grey to jet black, fine-grained sediments rich in quartz, shell fragments (gas- tropods, bivalves, corals, foraminifers) and heavy minerals.

Polished sections were made to study the internal structure of the oolites. Most of grains show concentric layering with or without a nucleus (Fig. 2). They are commonly made up of exceedingly fine-grained cryptocrystalline aggregates. Sometimes, one or more smaller grains are welded to form a bilobed or trilobed oolite. The nucleus when present is observed to be of variable composition: quartz, hematite, pyrite, granite fragment and foraminifer. Sometimes foraminifers are coated around to give oolitic shape (Fig. 2d). 

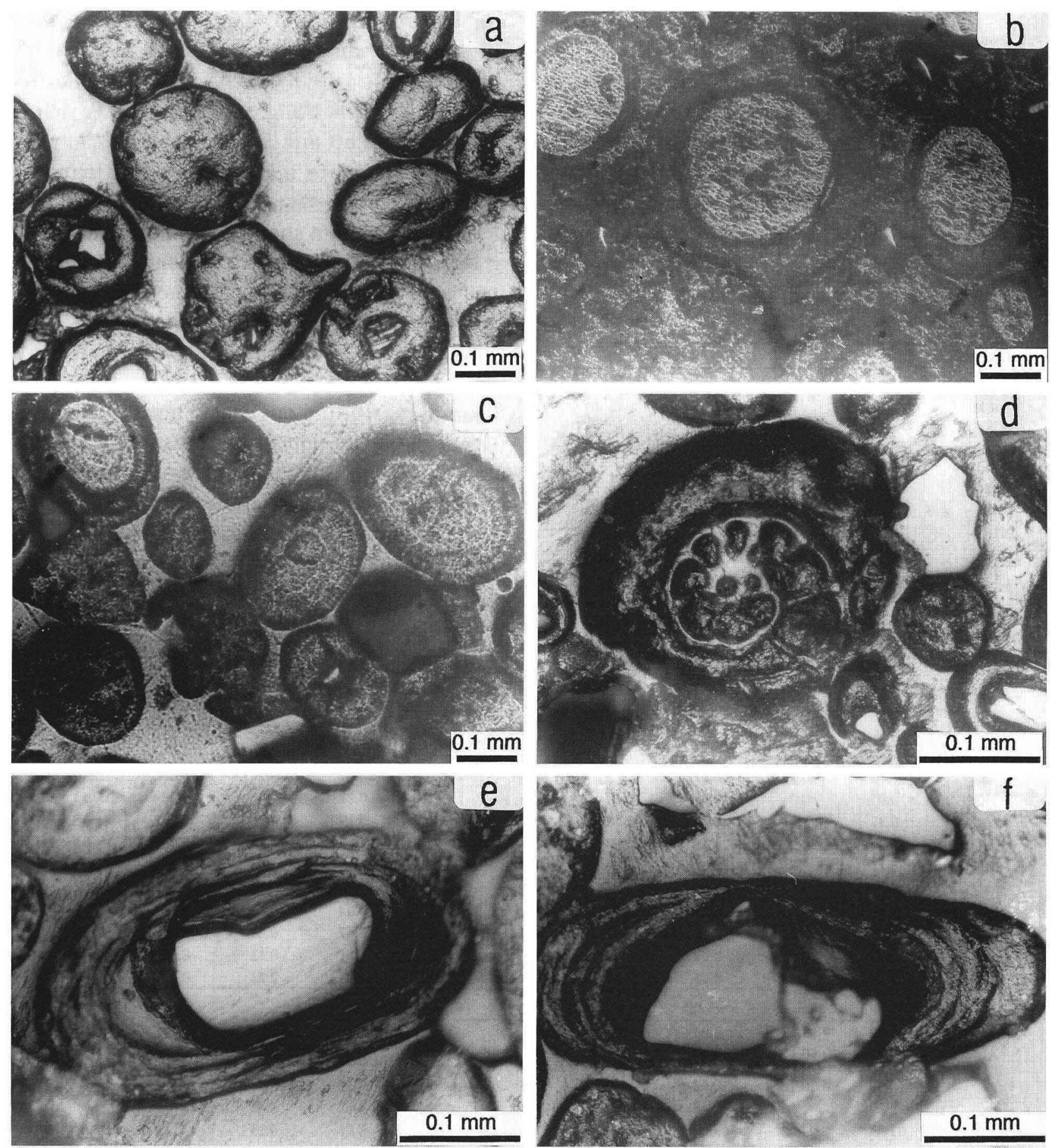

Fig. 2 Oolites in Mahanadi deltaic sediments. a: Grains with or without layering, b: Grains with core and rim, c: Grains with multiple layering without core, d: Grains showing infilling and coating around foraminifera, e: Grains with hematitic nucleus, f: Grains with quartz nucleus. Photographs a and b from Puri oolites; photographs c, d, e, and f from Bhagabanpur oolites. 


\section{MINERALOGY AND MINERAL CHEMISTRY}

It is difficult to separate oolite grains from associated quartz and other fragments by sink and float technique. Oolite concentrate has been obtained by isodynamic separation at low magnetic intensity. This clean oolite sample was powdered and used for XRD and chemical analysis. The bulk chemical analysis is presented in Table

Table 1 Bulk chemical analysis of oolites in Mahanadi deltaic sediments.

\begin{tabular}{lcr}
\hline \multirow{2}{*}{ Oxides } & \multicolumn{2}{c}{ Borehole } \\
\cline { 2 - 3 } & Bhagbanpur & \multicolumn{1}{c}{ Puri } \\
\hline $\mathrm{SiO}_{2}$ & 29.88 & 45.45 \\
$\mathrm{Al}_{2} \mathrm{O} 3$ & 5.36 & 6.34 \\
$\mathrm{Fe}_{2} \mathrm{O} 3$ & 17.59 & 18.97 \\
$\mathrm{FeO}$ & 12.1 & 3.01 \\
$\mathrm{CaO}$ & 6.85 & 1.05 \\
$\mathrm{MgO}$ & 4.41 & 6.42 \\
$\mathrm{~K} 2 \mathrm{O}$ & 1.56 & 2.37 \\
$\mathrm{H} 2 \mathrm{O}$ & 1.88 & 5.08 \\
$\mathrm{LOI}$ & 16.84 & 8.5 \\
\hline
\end{tabular}

Table 2 EPMA analysis of oolites in Mahanadi deltaic sediments.

\begin{tabular}{|c|c|c|c|c|c|c|c|c|c|c|}
\hline Sample & 1 & 2 & 3 & 4 & 5 & 6 & 7 & 8 & 9 & 10 \\
\hline Borehole & Bhagbanpur & Bhagbanpur & Puri & Puri & Bhagbanpur & Bhagbanpur & Bhagbanpur & Bhagbanpur & Puri & Bhagbanpur \\
\hline $\mathrm{SiO}_{2}$ & 48.16 & 48.77 & 46.01 & 46.08 & 30.24 & 25.37 & 28.07 & 26.23 & 35.85 & 37.7 \\
\hline $\mathrm{TiO}_{2}$ & 0.05 & 0.04 & 0.08 & 0.07 & 0.16 & 0.22 & 0.22 & 0.2 & 0.04 & 0.13 \\
\hline $\mathrm{Al}_{2} \mathrm{O}_{3}$ & 8.37 & 9.61 & 8.29 & 5.19 & 7.04 & 6.01 & 5.19 & 6.08 & 6.76 & 9.38 \\
\hline $\mathrm{Fe}(\mathrm{T})$ & 27.84 & 28.11 & 26.78 & 27.93 & 44.09 & 49.17 & 51.09 & 48.12 & 30.08 & 33 \\
\hline $\mathrm{MgO}$ & 5.15 & 5.24 & 5.66 & 7.88 & 5.54 & 4.67 & 4.68 & 4.96 & 14.79 & 5.76 \\
\hline $\mathrm{MnO}$ & - & - & 0.05 & 0.05 & - & - & - & - & 0.09 & 0.02 \\
\hline $\mathrm{P}_{2} \mathrm{O} 5$ & 0.13 & 0.13 & 0.08 & 0.04 & 0.36 & 0.63 & 0.04 & 0.34 & 0.05 & 0.15 \\
\hline $\mathrm{CaO}$ & 0.64 & 0.67 & 0.81 & 0.68 & 0.63 & 0.51 & 0.47 & 0.54 & 0.58 & 0.79 \\
\hline $\mathrm{Na}_{2} \mathrm{O}$ & 0.09 & 0.03 & 0.09 & 0.06 & 0.1 & 0.13 & 0.1 & 0.11 & 0.08 & 0.11 \\
\hline $\mathrm{K}_{2} \mathrm{O}$ & 5.95 & 5.86 & 4.15 & 4.71 & 2.56 & 2.11 & 2.02 & 2.23 & 0.73 & 2.77 \\
\hline & \multicolumn{4}{|c|}{ (Based on 8 cations) } & \multicolumn{4}{|c|}{ (Based on 10 cations) } & \multirow{12}{*}{\multicolumn{2}{|c|}{ Not determined }} \\
\hline $\mathrm{Si}$ & 3.88 & 3.83 & 3.81 & 3.59 & 3.57 & 3.14 & 3.38 & 3.24 & & \\
\hline $\mathrm{Al}$ & 0.12 & 0.17 & 0.19 & 0.41 & 0.43 & 0.86 & 0.62 & 0.76 & & \\
\hline $\mathrm{Al}$ & 0.67 & 0.72 & 0.62 & 0.44 & 0.56 & 0.03 & 0.11 & 0.11 & & \\
\hline $\mathrm{Fe}$ & 1.69 & 1.66 & 1.67 & 1.64 & 3.92 & 4.59 & 4.62 & 4.45 & & \\
\hline $\mathrm{Ti}$ & 0.003 & 0.002 & 0.004 & 0.004 & 0.02 & 0.02 & 0.01 & 0.13 & & \\
\hline $\mathrm{Mg}$ & 0.627 & 0.61 & 0.7 & 0.91 & 0.98 & 0.86 & 0.84 & 0.82 & & \\
\hline $\mathrm{Mn}$ & - & - & 0.002 & 0.003 & - & - & - & - & & \\
\hline $\mathrm{P}$ & 0.01 & 0.01 & 0.005 & 0.003 & 0.03 & 0.06 & 0.02 & 0.02 & & \\
\hline $\mathrm{Ca}$ & 0.08 & 0.08 & 0.13 & 0.1 & 0.08 & 0.07 & 0.06 & 0.08 & & \\
\hline $\mathrm{Na}$ & 0.02 & 0.02 & 0.03 & 0.02 & 0.02 & 0.04 & 0.02 & 0.04 & & \\
\hline $\mathrm{K}$ & 0.9 & 0.9 & 0.84 & 0.88 & 0.39 & 0.33 & 0.32 & 0.35 & & \\
\hline
\end{tabular}

1, 2, 3, 4: glauconitic composition; 5, 6, 7, 8: chamositic composition; 9, 10: mineral composition not determined.
1. The Puri sample matches with glauconite mineral composition while sample from Bhagbanpur having low silica, high iron and low potash appears closer to chamosite (a septa chlorite) composition. The Bhagbanpur sample is rich in ferrous iron, $\mathrm{CaO}$ and LOI probably due to presence of carbonate materials, like calcite and siderite in them.

XRD data did not show any iron silicate mineral but minerales like quartz, calcite, siderite and traces of ilmenite, feldspar, montmorillonite, chlorite, biotite, etc. are observd. Lack of X-ray reflection peaks characteristic of iron silicate phases reveal that these are present in amorphous state. To find out exact chemical composition of the oolite, fourteen grains (six from Puri and eight from Bhagbanpur) were subjected to electron probe micro analysis. Two to four points from each grains were analysed. All points in one grain show more or less uniform composition. In one grain (Fig. 2d), core and rim were analysed and they show similar chemical composition. Different grains in a sample show widely varying 
chemical composition. Average values for ten grains are presented in Table 2 . In eight grains (1 to 8 in Table 2), two sets of compositional ranges for $\mathrm{SiO}_{2}, \mathrm{Fe}_{2} \mathrm{O}_{3}{ }^{\left({ }^{t}\right)}$ and $\mathrm{K}_{2} \mathrm{O}$ were noted. In one set, $\mathrm{SiO}_{2}$ varies from 46 to $48 \%, \mathrm{Fe}_{2} \mathrm{O}_{3}{ }^{\left({ }^{t}\right)}$ from 27 to $28 \%$, and $\mathrm{K}_{2} \mathrm{O}$ from 4 to $6 \%$ corresponding with glauconite composition. In the other set, $\mathrm{SiO}_{2}$ varies from 25 to $30 \%, \mathrm{Fe}_{2} \mathrm{O}_{3}{ }^{\left({ }^{t}\right)}$ from 44 to $51 \%$, and $\mathrm{K}_{2} \mathrm{O}$ from 2 to $2.6 \%$ corresponding with chamosite composition. The calculated formula for glauconite composition is $\left(\mathrm{Ca}_{0.08-0.13} \mathrm{~K}_{0 \text { 84-0.90 }} \mathrm{Na}_{002-0.03}\right)$ $\left(\mathrm{Mg}_{061-0.91} \mathrm{Fe}^{2}+_{1.64-169} \mathrm{Al}_{0.44-0.72} \mathrm{Ti}_{0 \text { 002-0 004 }}\right) \quad\left(\mathrm{Si}_{3.59-388} \mathrm{Al}_{0.12-0.41}\right)$ $\mathrm{O}_{10}(\mathrm{OH})_{2}$ and for chamosite composition is $\left(\mathrm{Si}_{3.14-}\right.$

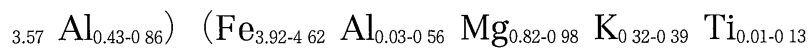
$\left.\mathrm{Ca}_{006-0.08} \mathrm{Na}_{0.02-0.04} \mathrm{P}_{003-0.06}\right) \mathrm{O}_{10}(\mathrm{OH})_{8}$ (Table 2). Puri oolites are mostly glauconite composition, while Bhagbanpur oolites contain mixture of glauconite and chamosite compositions. There are a few grains probed (Table 2, grains 9 and 10) which do neither match with the above two mineral compositions nor the other mineral phase. Pettijohn (1975) mentioned that among the iron silicates chamosite occurs both in granular and oolite state while glauconite usually occurs in granular form. In the present case, however, almost all grains irrespective of compositional variation show oolitic structure.

\section{DISCUSSION AND CONCLUSIONS}

The oolites in Mahanadi deltaic sediments of Orissa are always associated with very dark to black, fine-grained sediments with remains of marine shells and foraminfers. The dark grey and black sediments usually represent a reducing environment. The high amount of ferrous iron in Bhagbanpur oolites (Table 1) also support reducing environment. The foraminiferal taxa observed in the sediments also indicates brackish water to open-sea inner shelf condition under which sediments were deposited. Thus the oolites were formed in the shallow marine, reducing environmental condition along Orissa coast. They might have derived their magnesium and potassium from the sea water and other constituents from illite and mud as invoked by Hendricks and
Ross (1941), Light (1952), and Cloud (1955). The oolites with glauconite composition formed with less iron and more potash supply while chamositic composition formed with more iron and very less potash supply. There is no evidence of glauconitic materials forming from biotite as suggested by Galliher (1935).

A variety of chemical compounds, e.g. carbonates, silica, phosphate, silicates, hematite and limonite form oolites. In the present case, all the oolites are composed of hydrous iron silicates. They are composed of variable proportion of $\mathrm{Si}$, $\mathrm{Fe}, \mathrm{Al}, \mathrm{Mg}, \mathrm{K}$ and hydroxyl components. The majority of grains have glauconitic composition (as at Puri) or comprise a mixture of glauconitic and chamositic compositions (as at Bhagbanpur). A few compositions also exist, which are neither glauconitic nor chamositic. Literatures show that only chamosite among the iron silicates forms oolites whereas glauconite, greenalite, etc. do not form oolites (cf. Pettijohn, 1975). The present findings conclusively prove that variable proportions of $\mathrm{Si}, \mathrm{Fe}, \mathrm{Al}, \mathrm{Mg}, \mathrm{K}$, and $\mathrm{OH}$ can precipitate in shallow marine reducing environments as oolites in amorphous state.

\section{ACKNOWLEDGMENTS}

The first author (NKM) is very grateful to Dr. K.K. Dwivedy, Director, Atomic Minerals Division/Dept. of Atomic Energy, Govt. of India, Hyderabad and Dr. Mrs. Minati Roy, Scientist of the same organisation for their active assistance in the chemical and electron probe analysis on oolites. Comments by an anonymous reviewer helped to improve the final version of the paper.

\section{REFERENCES}

Cloud, P. E., 1955: Physical limits of glauconite formation. Bull. Am. Assoc. Petrol. Geologist, 39, 484-492.

Galliher, E. W., 1935: Glauconite genesis. Bull. Geol. Soc. Am, 46, 1351-1365.

Hendricks, S. B. and Ross, C. S., 1941: Chemical composition and genesis of glauconite and celadonite. Am. Mineralogist, 26, 683-691. 
Light, M. A., 1952: Evidences of authigenic and detrital glauconite. Science, 115, 73-75.

Mahalik, N. K., 1995: Subsurface geology and groundwater occurrence in southwestem sector of Mahanadi delta along the eastern coast of India. Proc. XV Annual Conf., National Assoc. Geograph. India (Spatial Dimensions in Geography), 1-14.

Pettijohn, F. J., 1975: Sedimentary Rocks, 3rd ed. Harper and Row, New York, 628p.

\section{インド，オリッサ州マハナディデルタ堆積物中の含鉄珪酸塩オーライト}

N. K. Mahalik · 前島＼cjkstart渉 - B. K. Mohapatra · B. R. Nayak, 1998, 堆積学研究, No, 48, 61-66

Mahalik, N. K., Maejima, W., Mohapatra, B. K. and Nayak, B. R., 1998:

Occurrence of iron silicate oolites in Mahanadi deltaic

sediments of Orissa, India. Jour. Sed. Soc. Japan, No. 48, 61-66

マハナデイデルタの臨海漸移帯では，地表下 $100 ３ 00 \mathrm{~m}$ の後期更新世堆積物中に含鉄珪酸塩

オーライトが多産する.オーライトは貝化石を含む暗灰色～黒色海成堆積物に伴なって産する. オーライトには同心円状の構造が良く発達して抢り, 核を持つものも持たないものもある。こ れらのオーライトは, 浅海域の還元環境下で, ほほ海緑石からシャモサイトに相当する様々な 組成の，鉄を含む含水珪酸塩が非晶質状態で沈澱して形成されたと考えられる. 